\title{
The Piano Plague: The Nineteenth-Century Medical Critique of Female Musical Education*
}

\author{
James Kennaway
}

\begin{abstract}
The role of music in nineteenth-century female education has been seen primarily in the context of the middle class cult of domesticity, and the relationship of music to medicine in the period has generally been viewed in terms of music therapy. Nevertheless, for much of the century there was serious medical discussion about the dangers of excessive music in girls' education. Many of the leading psychiatrists and gynaecologists of the nineteenth century argued that music could over-stimulate the nervous system, playing havoc with vulnerable female nerves and reproductive organs, and warned of the consequences of music lessons on the developing bodies of teenage girls. Two rival models of music's effects competed and were combined. One suggested that music led to illness by provoking sensuality, imagination and sexuality; the other argued that it was a source of neurasthenic fatigue because of intellectual strain.
\end{abstract}

Keywords: music; neurasthenia; nerves; 19th-c. gynaecology; menstruation

Nineteenth-century medicine's qualms about the possible effects of "excessive" education on female health have been well documented. In particular, debates on the access of women to university provoked many physicians to argue that too much intellectual strain went again women's nature, damaging the nervous system and compromising female sexuality and fertility ${ }^{1}$. In contrast, the role of music in nineteenth-century female education has been seen primarily in the context of the middle class cult of domesticity, and the

* The author would like to thank the Wellcome Trust for its generous support.

1 Clarke 1875; Maudsley 1874; 466-483; Tait 1883; Thorburn 1884; Burstyn 1973.

Dr James Kennaway, Wellcome Research Fellow, Centre for the History of Medicine and Disease, Wolfson Research Institute, University of Durham, University Boulevard, Stockton-onTees, TS17 6BH, United Kingdom, tel.+44 7946183084 (james.kennaway@durham.ac.uk). 
relationship of music to medicine in the period has generally been viewed in terms of music therapy. Nevertheless, for much of the century there was serious medical discussion about the potential dangers of excessive music in girls' education. Although some prominent medical critics of female education in general such as Henry Maudsley and Edward Clarke paid little attention to music or in fact regarded it as a respectable accomplishment for girls, many of the era's leading psychiatrists and gynaecologists argued that music could not only excite the imagination in the same way as a novel but also over-stimulate the nervous system directly, playing havoc with vulnerable female nerves and reproductive organs, and warned of the consequences of music lessons on the developing bodies of teenage girls ${ }^{2}$. In so doing they created a serious medical counterpart to the discussion of what the critic Eduard Hanslick called the "Klavierseuche" - the piano plague ${ }^{3}$.

This paper will examine this medical critique of female musical education in the context of contemporary theories of the role of nervous stimulation and exhaustion in the aetiology of disease. It seems that there were two rival implicit models of music's pathological effects of women, although they were often combined. On the one hand, one sees the idea of female music making as a source of over-stimulating sensuality akin to the excessive unconsummated sexual excitement that was believed led to nervous sickness. On the other hand, there was the view that music was a dry intellectual pursuit, a potential cause of modern fatigue that could lead to neurasthenia among women in the same way as "excessive" education. Thus one sees contradictory thinking about music's relationship to schoolwork. Some physicians portrayed music as an extension of academic life, but others saw it as a relief from the intellectual work, while a third group argued that hard study would be a welcome change from music's frivolity and sensuality. To examine the interaction of these theories and how they relate to political and medical debates on the New Woman and the nature of music, the first section will consider it in relation to the neurasthenia diagnosis, the discipline of "school hygiene", and will be followed by a discussion of the debate on the perils of music for women's gynaecological health.

2 Anon 1824, 177; Porter 1988.

3 Hanslick 1900. 


\section{The Piano and Over-Stimulated Sensuality and Neurasthenic Fatigue}

The key image of the female musician in the nineteenth century is surely that of the domestic piano player. Within the context of the dominant "twospheres" ideology, private music making in the home was generally regarded as an especially female activity ${ }^{4}$. Indeed, from the eighteenth century playing the keyboard at home had become a central part of the habitus of female gentility and the construction of gender and class roles 5 . In contrast to the widespread hostility shown towards women who were involved in public life as intellectuals as "bluestockings", this private musical sphere was on the whole eminently respectable. Certain female professional musicians, such as Clara Schumann, even found a place in nineteenth-century public life. However, they were tolerated only within limits, with certain instruments and not expected to have any success at composition. This reflected the period's profoundly ambiguous attitude to the relationship between music and gender. On the one hand, music was a sensual, feminine art, on the other hand, composition and serious musicianship were regarded as a heroic masculine business. The attitude of physicians reflected this ambiguity, with many overtly approving of music as a ladylike pastime, but with others, as we shall see, denouncing the physical effects of music on women in the strongest terms.

Nineteenth-century medical doubts about the role of music in female education drew on ideas of music as a form of nerve stimulation that had developed during the previous century. In contrast to the speculative metaphysics of the previous periods, Enlightenment considerations of music therapy, such as Richard Brocklesby's 1749 Reflections on Antient and Modern Musick emphasized the power of music on the nerves ${ }^{6}$. However, this was viewed in the context of the culture of sensibility and it was generally assumed that music's essential effect was to refine the nerves rather than to over-stimulate them. Only at the end of the century did a systematic medical critique of musical stimulation emerge as physicians such as Peter Lichtenthal incorporated thinking on nerve stimulation as a cause of disease developed by the likes of Samuel Auguste Tissot, William Cullen and John Brown into works on the medical effects of music ${ }^{7}$. In the following decades the dangers of music to female health became a commonplace in books on dietetics, etiquette, psychiatry and music criticism, especially in Britain and Germany 8 .

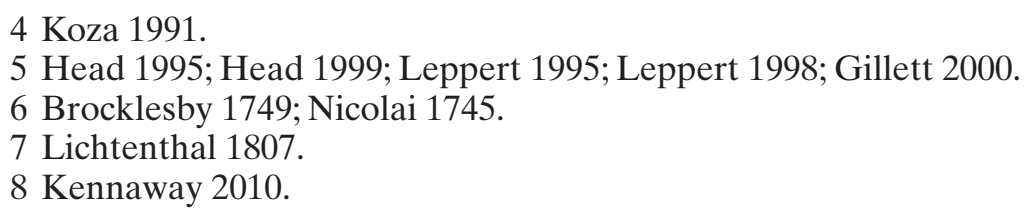


The medical dangers of music were on the whole related to women, in the context of assumptions about the vulnerability of female nerves that had been commonplace since the Enlightenment ${ }^{9}$. Especially in the first half of the nineteenth century, the medical critique of female music-making focused on its supposed excessive sensibility, its sensuality and its association with an idle elite. For example, the prominent Irish doctor James Johnson argued in his 1837 dietetic book The Economy of Health that music created nerves that "are ultimately unstrung by perpetual vibration", leading to "depression of spirits, often approaching to hypochondriacism". For young ladies, "whose sensitive nerves, susceptible feelings, exquisite sympathies, tender affections, and delicate organization, are excited, stimulated, electrified", this could be disastrous for "the countenance, the complexion, the gait - the whole physical and moral constitution of the female"10. Where Johnson fretted about the dangers of the sedentary life that music involves, he was part of a tradition that stretched from the humours to modern medicine, but the language of nerves and electricity shows the influence of the idea of music as a direct stimulant ${ }^{11}$.

In the later decades of the nineteenth century, this model of music as a sensual stimulant was challenged by and combined with the neurasthenia diagnosis of the American physician George Miller Beard ${ }^{12}$. Although his model of the aetiology of sickness owed much to Enlightenment thinking on stimulation (albeit in a new terminological guise), other elements were more innovative. Beard gave a clearer role for sexual tension in the causation of nervous illness, and crucially he saw the strains and fatigue of the modern world as a primary cause of what he saw a peculiarly "American" nervousness, shifting the focus from the idle luxury that George Cheyne had blamed for the "English Malady"13. His medical critique of modern lifestyles combined the thermodynamics of the German scientists Hermann Helmholtz and Julius Robert Mayer with the electrophysiology of Du Bois-Reymond to create a view of the body as a battery that could be run down through

9 Indeed, Robert Martensen has argued that supposed differences between the nervous systems of men and women were the basis of a general gender dichotomy in understandings of the body. Martensen 1994; Laqueur 1990; Stolberg 2003; Nye/Park 1991.

10 Johnson 1837, 48.

11 The popular English writer Eliza Cook echoed these views in an 1850 article which argued that hours "on a music stool, drumming at a piano-forte is another fertile source of nervousness among young women. Female children are too ordinarily set to music whether they have an ear for it or not [...] laying in a stock of 'nerves', sick head-aches, and morbid irritability [...]. The demons of hysteria and melancholy might hover over a group of young ladies so brought up [...]." Cook 1850, 2.

12 Beard 1880; Beard 1881; Beard 1905.

13 Porter 2001. 
over-stimulation $^{14}$. In this context, music could be seen as a source of fatigue rather than excessive sensuality. As the Canadian Grant Allen put it in his 1877 Physiological Aesthetics, auditory nerves could be "wearied by over-use or jarred by discordant sounds", and "all dissonance is fatigue" 15 .

This understanding of music as a cause of neurasthenic fatigue was reflected in the thinking of many physicians. Although many nineteenthcentury physicians advocated forms of music therapy in psychiatry, many others regarded music as, in the words of the leading Dutch psychiatrist Jacob van Deventer, a "dangerous stimulant" for people suffering from neurasthenia ${ }^{16}$. The French physician Fernand Levillian, in his 1901 Hygiène des Gens Nerveux (Hygiene of Nervous People), pointed to music as a source of neurasthenic exhaustion, writing that, the "excitations of the ear [...] are often the starting point for real nervous fatigue that aggravates the neuropathic state of over-excitable subjects"17. Similarly, the German physician Alfred Baumgarten wrote that, "music can over-stimulate some of them. The more the neurasthenic understands of music, the worse the level of overstimulation [...]. Neurasthenics who are themselves musicians must be prevented from regularly playing music or singing during the course of their cure" ${ }^{18}$. Clinical practice reflected this view of music's potential neurasthenic and psychotic effects. One famous example is provided by the case of the Parisian pianist Hersilie Rouy, who spent fifteen years locked up in an asylum. Louis Florentin Calmeil, her psychiatrist at the Charenton asylum, suggested that her insanity (which she vehemently disputed) had been caused by excessive music. In a letter of 22 May 1869 he wrote that, "she tired her nervous system by an excess of late nights and by her diligence in study and in her devotion to music"19.

Such apparent female vulnerability in the face of musical stimulation led to considerable debate about whether girls should play the piano at all, based in part on the kind of fears of over-stimulated sensuality that James Johnson expressed but also on anxiety about the neurasthenic fatigue that might

14 Rabinbach 1990; Roelcke 1999, 112-121; Rosenberg 1962; Sicherman 1977; Killen 2006.

15 Allen 1877, 98.

16 van Deventer 1891, 26-27; Anon. 1892, 63.

17 «Les excitations de l'ouie, musicale ou autres, sont donc souvent le point de depart d'une réelle fatigue nerveuse qui entretient ou aggrave l'etat névropathique des sujets trop excitables.» Levillian 1901, 142.

18 «Musikalische Genüsse sind Neurasthenischen nicht immer zuträglich. Musik wirkt auf manche dieser Kranken erregend ein. Je grösser das musikalische Verständnis des Neurasthenischen, desto schlimmer dann der Erregungszustand [...]. Neurasthenischen, welche selbst ausübende Künstler sind, muss indessen während der Dauer der Kur die regelmässige Ausübung von Musik oder Gesang untersagt werden.» Baumgarten 1914, 253.

19 Cited in Appignanesi 2008, 104; see also Wilson 2010; Rouy 1883. 
result, mixing the two models of music's medical dangers. A central figure in this discourse was Richard von Krafft-Ebing, whose views were widely repeated, not always with acknowledgement ${ }^{20}$. He suggested that, "one of the monstrosities of our modern civilization is the idea that every child of the higher classes must have a musical education", he wrote. "In cases of limited talent studying the piano is an inadequate achievement which makes heavy demands on the physical and mental strength of the player and often creates nervousness and in the case of untalented girls, if practiced too intensively or unwillingly, can become the cause of serious nervous diseases." 21

Others went into more details about the medical consequences of excessive female piano playing. J.Herbert Dixon, in The Medical Magazine in 1900, condemned excessive piano practice by girls, warning that "the baneful influence of the continual vibrations on the organ of Corti, and so on the brain" could lead to "pronounced neurasthenia" with symptoms such as "headaches, neuralgia, nervous twitchings, hysteria, melancholia, madness, etc"22. Similarly, in his 1902 polemic Wider die Musik! Die gegenwärtige Musiksucht und ihre unheilvollen Wirkungen (Against Music! The Current Addiction to Music and its Baleful Effects), the physician Norbert Grabowsky condemned the dangers of the piano to women, comparing its effects to that of alcohol on men ${ }^{23}$. "The modern piano plague", he claimed, damaged culture, the family and could lead to "symptoms of exhaustion in the brain (nervousness), as well as disturbances of the circulation, nosebleeds, regular headaches, excessive loss of weight and anaemia"24. Grabowsky quoted the Berliner Zeitung newspaper blaming "nerve-stimulating musical practice" for a wave of sickness among girls at Elisabeth School in Berlin, and went as far as to suggest that legislation should control $\mathrm{it}^{25}$.

As the Berliner Zeitung reflected, the booming field of "School Hygiene" also concerned itself with the health consequences of music lessons, espe-

20 See Wolf 1896, 13; Krafft-Ebing 1884, 35; Weyl 1914, 6:480; Berger 1897, 27. Likewise, Hermann Oppenheim advocated use of silent keyboard in certain cases to reduce the stimulation involved in piano practice: Oppenheim 1907, 61.

21 «Zu den Ungeheuerlichkeiten unseres modernen Culturlebens gehört auch die Idee, dass jedes Kind aus besseren Ständen musikalische Bildung haben muss. Nach der Begabung wird nicht gefragt. Die Mode beansprucht es, dass die jungen Leute Clavier klimpern können [...]. Bei mangelndem Talent ist das Clavierstudium eine inadequate Leistung, die, da sie die körperliche und geistige Kraft an und für sich schon erheblich in Anspruch nimmt, nicht selten Nervosität hervorruft und wenn sie von talentlosen Mädchen zu intensiv oder widerwillig betrieben wird, den Grund zu schweren Nervenkrankungen legt.» Krafft-Ebing 1903, 59; see also Pudor 1892, 32.

22 Dixon 1900, 294-5; see also Ufer 1890, 10. Westmacott 1879, 8; Cutler 1867, 26-7.

23 Grabowsky 1892, 29.

24 Grabowsky 1892, 43-53. See also W.F. 1899, 636-7.

25 «Nervenreizende musikalische Übung.» Grabowsky 1892, 53, 45. 
cially for girls. For example, the Viennese Professor Leo Burgerstein's Handbuch der Schulhygiene (Handbook of School Hygiene) of 1902 stated that girls "must not be damaged" with music lessons, asserting that they are "a serious danger." "Mediocre pupils who are not gifted at music", he argued, "become not only an ordeal for other people, but also form the largest contingent of the "victims of excessive strain". ${ }^{26}$ In the early decades of the century, this was principally a concern in relation to the daughters of the elite, but the rise of mass education and cheaper factory-produced musical instruments over time meant that it became a matter for "school hygiene" discourse and, more broadly, part of the highly politicized debate on the degeneration of the masses ${ }^{27}$. In this context, music was essentially portrayed as a source of fatigue, an additional intellectual strain for which girls were supposedly ill equipped, a model of music's ill effects that appears to have become more influential in the decades before World War One.

\section{Music and Gynaecology}

The nervous exhaustion supposedly created by excessive studying of music was intimately connected to sexuality. Sexual excitation without (legitimate married) consummation was widely regarded as a prime cause of neurasthenia. Beard himself advocated not only marriage but also the electrocution of patients' genitals as a cure for this condition. Music's apparent sensuality meant that it was often put into the context of the nerve-uterus nexus that dominated medical understandings of the female body. Often these concerns about music were related to moral physiology, with the assumption that music, like the imagination, could over-excite the passions and lead to sickness via the mind. In 1863 the Silesian physician Hermann Lebert suggested that hysteria was most common among women with a strong sex drive,

26 «Eine grosse Gefahr [...] in dem Musikunterrichte. Mittelmässige, für Musik nicht veranlagte Schüler werden durch diese Übungstunden nicht nur zu einer Qual für ihre Mitmenschen, sondern stellen auch das Hauptkontigent der 〈Opfer der Überbürdung〉. Man gebe in solchen Fällen den Musikunterricht auf, und in kurzer Zeit wird der normale Geisteszustand zurückkehren. Der Versuch, Kinder in anderen Unterrichtsfächern zu befreien, ohne gleichzeitig die Musikstunden aufzulassen, ist ganz verfehlt und sanitär nicht gerechtfertigt.» Burgerstein 1902, 2:889. Similarly, R. Wehner's 1904 Enzyklopädisches Handbuch der Schulhygiene (Encyclopaedic Handbook of School Hygiene) warned of the dangers of piano lessons for untalented pupils with socially ambitious mothers, with a graph to show the link between female over-exertion and nervousness. Wehner 1904, 406-7. Ludwig Wagner's 1898 Unterricht und Ermüdung (Lesson and Exhaustion) warns not to send schoolchildren to music lessons if they are academically weak, since this will further strain their nerves. Wagner 1898, 117.

27 Pick 1989. 
stimulated by music, sentimentality and masturbation ${ }^{28}$. This was the context for the debate on the question of whether women's weak nerves made them unsuitable for the work of tuning pianos, which concluded that married (i.e. legitimately sexual experienced) women, could manage it, but not that their younger (virginal) counterparts would be dangerously over-stimulated ${ }^{29}$.

The assumed links between the health threat posed by music and sexuality led to a surprising level of interest in the subject among gynaecologists. The consequences for female fertility and reproductive health, especially menstruation, were a common topic of debate during the final decades of the nineteenth century. The idea that menstruation made women too weak for serious education and that education might adversely affect their menstrual cycle and reproductive health were a cornerstone of anti-feminist objections to female education in this period. For example, the English psychiatrist Henry Maudsley, whose article "Sex in Mind and Education" was a significant intervention in this discussion, wrote that stimulation of the female brain was dangerous after the "establishment of periodical functions" "30. Similarly, the Scottish gynaecologist Alexander Skene argued that an "unnatural" education could "over-stimulate the brain and nervous system" and lead to "menstrual derangement and sterility"31.

A surprising and contradictory range of views concerning the relationship between female music making and the functions of healthy female reproduction was put forward by many of the most famous gynaecologists of the century. Already in his 1809 Dissertatio Inauguralis de Musices vi Medica, the German physician Johannes Ludwig Chemnitz discussed the relationship between music and menstruation, noting that a Dr Clark had reported using music in a case of menstrual mania in the Gentleman's Magazine in 1778, and that Louis Desbout's 1784 Dissertation sur l'effet de la Musique dans les Maladies nerveuses had also examined the topic ${ }^{32}$. Although many connected music to menstruation, there was no consensus about the nature of its effects. Indeed, although the assumed connection between music and menstruation was a commonplace, the anecdotal evidence given by physicians suggested opposite conclusions. Some, taking the view that music was a potential source of sensuality, suggested that excessive music could over-stimulate the

28 «Jedoch ist sie bei nervösen reizbaren Frauen mit sehr entwickeltem Geschlechtssinn am häufigsten [...] zu grosse Einbildungskraft, Überreizen derselben durch Lesen von Romanen, durch Musik, durch Sentimentalität und die dieselbe oft begleitende Onanie.» Lebert 1863, 2:656.

29 Witte 1893, 261-3.

30 Maudsley $1874,199$.

31 Skene 1889. Skene had no objections to musical education. See Skene 1889, 93; Smith-Rosenberg/Rosenberg 1973.

32 Cited in Chemnitz 1809, 52-3. 
body and lead to premature menstruation and sexualisation ${ }^{33}$. Other nineteenth-century gynaecologists, however, portrayed music more in terms of neurasthenic fatigue, arguing that music could so strain the nervous system that it could delay menstruation in teenage girls and prevent it among adult women.

The French physician Paul Briquet's 1859 Traité clinique et thérapeutique de l'hystérie was one of many books to suggest that music could lead to premature menstruation ${ }^{34}$. In some ways Briquet was well disposed towards music's physical effects on women, but his colleague, Adam Raciborski, the Paris-based Polish specialist in gynaecology who established spontaneous ovulation, took a tougher line in his 1868 Traité de la Menstruation, pointing to the French psychiatrist Jean-Pierre Falret's work linking music to nerves and suicide ${ }^{35}$. Raciborski expanded on Briquet's theory of the relationship between music and menstruation, writing that music could "promote the development of Graafian follicles [in the ovaries] and precipitate the onset of ovulation" 36 . And he mused that the popularity of music among young ladies of the elite might explain why menstruation appeared to begin earlier in that class. His comments overtly linked the effects of music on menstruation to sexuality, writing that because of its effect on the nervous system, "music can serve as a stimulant in the genital sense, that we believe allows us to conclude that it can perhaps be regarded as a cause of the relative precocity of puberty among young girls of wealthy families" ${ }^{37}$. A quiet life in the countryside, away from musical over-stimulation, would be his advice for the daughters of nervous mothers in order to avoid provoking "ovarian orgasm through nervous excitement" 38 .

33 This theory that has resurfaced in recent years, as speculation has grown about cultural factors in the light of the apparent widespread earlier onset of menstruation. See Lemonick 2000; Deluzio 2007; Shail/Howie 2005; Showalter 1970; Walker 1997; Bullough/Voght 1993; Vertinsky 1990.

34 Briquet 1859, 608.

35 Briquet 1868, 320; Falret 1822, 22-23.

36 «En traitant, dans le chapitre précédent, de l'influence de la musique sur l'époque de la puberté, nous avons laissé une assez large part a son action sur l'économie; nous avons même admis que son exercice habituel pouvait favoriser le développement des follicules de Graaf et précipiter la marche de l'ovulation.» Raciborski 1868,319.

37 «Cependant il suffirait qu'il fût démontré que la musique peut servir d'excitant au sens génital, pour que nous nous croyions autorisé d'en conclure qu'elle peut être considérée comme une cause capable de rendre compte de la précocité relative de la puberté que l'on remarque chez les jeunes filles des familles riches.» Raciborski 1868, 212-213.

38 «Les filles nées de pareilles mères ont besoin du calme, elles doivent être élevées à l'abri de vives émotions; la vie de campagne leur convient mieux, et il serait même préférable qu'elles fussent réglées relativement plus tard, afin de rien ajouter du côté de l'orgasme ovarien de la menstruation aux dispositions naturelles à la surexcitation nerveuse.» Raciborski 1868, 320 . 
The notion that musical over-stimulation among teenage girls could lead to premature menstruation was expanded by the leading Scottish gynaecological surgeon Lawson Tait in his 1877 Diseases of Women, where he blamed music for cases of ovaritis and its related excessive menstrual blood loss ${ }^{39}$. He wrote that in such circumstances, "the patient should be removed from school, and that for six months, all instruction, especially in music, should cease". He argued that music lessons were the cause of "a great deal of menstrual mischief" ${ }^{\prime 4}$. Other doctors took an even tougher line. In his 1871 System der Hygiene, the German physician and noted medical opponent of music Eduard Reich went as far as to suggest that the erotic effect of music could have startling consequences for young women. "The relationship between music and sex life and especially menstruation is hardly ever mentioned", he lamented. "Excessive music causes significant excitation to the whole nervous system and especially to the imagination, and this can lead in more than a few cases to premature awakening of the sex drive and the premature start of menstruation" ${ }^{41}$. Nor did Reich consider early menstruation a minor issue. It could, he wrote, lead to "passions, despair, suicide, vice, crime, madness, melancholy, hysteria" ${ }^{42}$. The dangers were such that Reich seriously suggested banning "immoral music" on health grounds ${ }^{43}$.

In sharp contrast to these theories of the link between music and premature or excessive menstruation, other physicians argued that music was such a strain on young girls' bodies that it could in fact prevent menstruation. For instance, in his 1840 book De la Menstruation considerée dans ses Rapports physiologiques et pathologiques, the French physician and psychiatrist Alexandre Brierre de Boismont argued that music can lead to lack of menstruation, citing Broussais ${ }^{44}$. "No sooner can a child express its first feelings, then one lets it make ravishing music and devote hours to this art form the nervous system, which is already so excitable, becomes even more excitable". He even implies that, "because of music's effects on menstruation", it would be desirable (but unrealistic) to ban it. However, unlike many of his contemporaries, rather than regarding music as a form of education

39 Tait 1877; see Tilt 1851, xxv; Golditch 2002,152-156.

40 Tait 1877, 205; see also Tait, 1880, 90.

41 «Von dem Verhältnisse der Musik zum Geschlechts-Leben und insbesondere zur Menstruation ist kaum irgendwo die Rede. [...] Durch Übermass der Musik wird das ganze Nervensystem und wird insbesondere die Phantasie in bedeutende Aufregung versetzt, und hierdurch in einer nicht geringen Zahl von Fällen nicht wenig zu frühzeitigem Erwachen des Geschlecht-Triebes, zu frühzeitigem Erscheinen der Menstruation beigetragen.» Reich 1871, 252.

42 Reich 1872, 155.

43 Reich 1872, 110.

44 Brierre de Boismont 1840, 301. 
that should not been pushed too far with girls, he portrayed it as a sensual exercise that could be counteracted by formal education, by gymnastic exercises, intellectual work and more serious tasks than those that young girls normally devote themselves to ${ }^{45}$.

More typical of those who argued that music could delay menstruation was the view that it was a cause of neurasthenic fatigue just like excessive education. This was particularly true among doctors in the United States, the home of neurasthenia. The leading proponent of this theory there was the influential gynaecologist Thomas Addis Emmet, who argued in his Principles and Practice of Gynaecology of 1884 that music's emotional influence made it "capable of arresting the development of the uterus and ovaries" 46 . Rather than call for girls to undertake more academic work as Boismont had, Emmet regarded female education in general as a medical disaster, writing that, "it is not practicable to educate a girl by the same method found best for the boy, without entailing serious consequences, for the ovaries will always be arrested in their growth if the brain is forced" 47 . Emmet's views were widely shared. For instance, the Colorado physician Hubert Work, who later ran for the Senate and served as US Postmaster General under Harding, gave a series of case studies of girls whose musical education had adversely affected their menstruation and general health ${ }^{48}$.

The association of female music-making with the subject of the higher education of women put the medical critique of music into the context of the sometimes bitter political debate on the "New Woman." "The ultra 'New Woman," Hubert Work wrote in his discussion of music's dangers, "is [...]

45 «Mais il y a d'autres règles à tracer pour le genre de vie: on commence de très-bonne heure, chez les demoiselles, l'étude des arts d'agrément: à peine l'enfant exprime-t-il ses premières sensation, qu'on fait résonner à ses oreilles les accords si enivrants de la musique; des heures entières sont données a cet art puissant. La danse, la peinture viennent se joindre à la musique, et le système nerveux, déjà si irritable, le devient bien plus encore à l'aide de pareils stimulants. Dans notre état social, et malheureusement ils ne se perfectionnent que par des années d'étude; mais ne peut-on contrebalancer leur action sur le système nerveux, et par suite sur la menstruation, par des exercices gymnastiques, par la culture des travaux intellectuels, par des travaux plus sérieux que ceux auxquels se livrent habituellement les jeunes personnes?» Brierre de Boismont 1840, 197.

46 Emmet 1884, 19.

47 Emmet 1884, 20.

48 Sixteen-year-old "Miss H." was "of healthy parentage and [...] good health up to two years ago, when she menstruated normally." Alas, "one year ago a misguided friend gave her a piano, and a music master was employed to further stimulate the waning energies. After a few months harassing, she requested medical advice [...]. She had become unable to wash dishes without dropping them, and a few minutes' piano practice would unnerve her for the day." Similarly eighteen-year-old "Miss D." was so strained by "long hours at the desk [...] followed by an hour's piano practice after school" that she "had practically ceased to menstruate. If accomplished at all it is with much pain and little flow. The chest is distorted, and she is an invalid, a physical maldevelopment and a neurasthenic." Work 1896, 221. 
the result of blighted instincts evolved in place of distinctly feminine emotion" ${ }^{49}$. Another American physician writing in the same journal, Frank Parsons Norbury, also made a strong connection between the health consequences of music and the New Woman, blaming "overwork" for most mental illness among women, which led, he argued, to a "broken down nervous system" and broken engagements (i.e. failed sexuality, not the excessive sexuality that other physicians had feared). He placed music lessons at the heart of his critique of female education, writing that, "I have observed that [female] students of music afford typical cases of neurasthenia:i.e., there is more profound general nervous disturbance than in cases of overwork from mental work alone [...]. In one graduating class from a conservatory of music I had four cases, three of whom had to be stimulated to enable them to carry out their part on the program" $"$.

In the case of opponents of musical education such as Emmet, Norbury or Work, the medical hostility is clearer simply part of a broader objection to female education, and indeed female interference beyond the domestic sphere in general. This essentially political aspect certainly explains much of the medical critique of music in female education in this period. In the face of the collapse of the traditional ideological underpinnings of gender hierarchies, medicine, especially gynaecology, was used to provide a rationale for the status quo. The model of music as a source of mental strain associated with neurasthenia seemed to offer a clear rationale against music just as much to female higher education in general. However, this does not explain other aspects of the debate, such as why music's position as a healthy, domestic refinement for ladies was apparently so contested by some physicians when others blithely accepted it as a respectable and genteel pastime, or why other physicians, notably Brierre de Boismont, regarded intellectual study not as a similar threat to female health as music, but as an antidote.

This question relates to music's essentially ambiguous position as an art that is both rational, mathematical and at the same time sensual and irrational, which in terms of female education amounts to asking whether music was a dry subject that would strain the female brain or a sensual one that would over-stimulate the imagination and the body. The very nature of music therefore meant that both models of music's pathological effects could appeal to obvious aspects of music. The fatigue paradigm of neurasthenia meant that music could be a medical threat even if it remained chaste and intellectual. On the other hand, musical sensuality, the "undue sexual excitement" that Norbury saw as central to music's dangers, had been criticized on moral

49 Work 1896, 222.

50 Norbury 1896, 112. 
grounds since Plato, but was now incorporated into a medical critique of female sexual excitement as bad for the nerves ${ }^{51}$. This older traditional moral/medical critique of music's sensuality seems to have proved the more resilient. Although the notion that female education, including musical education, is a source of nervous fatigue generally went out of fashion during the twentieth century, the idea of music as a potential cause of hysteria and sickness among women continued into the twentieth century, for instance in the context of Beatlemania. ${ }^{52}$

\section{Bibliography}

Allen, Grant, Physiological Aesthetics (London 1877)

Anon, "Nervous, and Other Diseases, Caused by Novel Reading," Family Oracle of Health 1 (1824) 177, "The Influence of Music on Mental Disorders," Journal of Nervous and Mental Disease (1892) 62-64

Appignanesi, Lisa, Mad, Bad and Sad: A History of Women and Mind Doctors (London 2008) Baumgarten, Alfred, Neurasthenie: Wesen, Heilung, Vorbeugung (Woerishofen 1914)

Beard, George Miller, American Nervousness (New York 1881)

Beard, George Miller, A Practical Treatise on Nervous Exhaustion (Neurasthenia) (New York 1880)

Beard, George Miller, Sexual Neurasthenia (New York 1884)

Berger, Paul, Die Nervenschwäche (Neurasthenie) (Berlin 1897)

Brierre de Boismont, Alexandre, De la Menstruation considerée dans ses Rapports physiologiques et pathologiques (Paris 1840)

Briquet, Paul, Traité clinique et thérapeutique de l'hystérie (Paris 1859)

Brocklesby, Richard, Reflections on Antient and Modern Musick (London 1749)

Bullough Vern/Martha Voght, "Women, Menstruation and Nineteenth-Century Medicine," Bulletin of the History of Medicine 47 (1993) 66-82

Burgerstein, Leo, Handbuch der Schulhygiene (Jena 1902)

Burstyn, Joan N., "Education and Sex:The Medical Case against Higher Education for Women in England, 1870-1900," Proceedings of the American Philosophical Society 117 (1973) 78-89

Chemnitz, Johannes Ludwig, Dissertatio Inauguralis de Musices vi Medica (Göttingen 1809)

Clarke, Edward H., Sex in Education (Boston 1875)

Cook, Eliza, "The Occupation and Health of Young Ladies," Eliza Cook's Journal 3 (Saturday 4 May, 1850) 1-3

Cutler, Helen R., "The Influence of Sound," Arthur's Home Magazine (July 1867) 26-27

Deluzio, Crista, Female Adolescence in American Scientific Thought (Baltimore 2007)

van Deventer, Jacob, "De Invloed der toonkunst op psycho-pathologische toestanden," Psychiatrische Bladen 9 (1891) 14-30

Dixon, J. Herbert, "Music and Medicine", The Medical Magazine 9 (1900) 290-300

Emmet, Thomas Addis, The Principles and Practice of Gynaecology (Philadelphia 1884)

Falret, Jean-Pierre, De l'hypochondrie et du suicide (Paris 1822)

Gillett, Paula, Musical Women in England, 1870-1914 (Basingstoke 2000)

Golditch, Ira, "Lawson Tait: The Forgotten Gynecologist," Obstetrics and Gynecology 99 (2002) 152-156

Grabowsky, Norbert, Wider die Musik! Die gegenwärtige Musiksucht und ihre unheilvollen Wirkungen (Dresden 1892)

51 Norbury 1896,112-113.

52 Sargant 1974. 
Hanslick, Eduard, "Gemeine, schädliche und gemeinschädliche Klavierspielerei," in: Eduard Hanslick, Aus neuer und neuester Zeit. Der Modernen Oper IX. Theil. Musikalische Kritiken und Schilderungen (Berlin 1900)

Head, Matthew, “'If the Pretty Little Hand Won't Stretch': Music for the Fair Sex in Eighteenth Century Germany," Journal of the American Musicological Society 52 (1999) 205-254

Head, Matthew, "Like Beauty Spots on the Face of a Man": Gender in $18^{\text {th }}$ Century NorthGerman Discourse on Genre," Journal of Musicology 13 (1995) 143-168

Johnson, James, The Economy of Health, or the Stream of Human Life from the Cradle to the Grave, with Reflections Moral, Physical and Philosophical on the Successive Phases of Human Existence (London 1837)

Kennaway, James, "From Sensibility to Pathology," Journal of the History of Medicine and Allied Sciences 65 (2010) 396-426

Killen, Andreas, Berlin Electropolis: Shock, Nerves and German Modernity (Berkeley and Los Angeles 2006)

Koza, Julia Eklund, "Music and the Feminine Sphere: Images of Women as Musicians in Godey's Lady's Book 1830-1877," The Musical Quarterly 75.2 (1991) 103-129

Krafft-Ebing, Richard von, Über Nervosität (Vienna 1884)

Krafft-Ebing, Richard von, Über gesunde und kranke Nerven (Tübingen 1903)

Laqueur, Thomas, Making Sex: Body and Gender from the Greeks to Freud (Cambridge 1990)

Lebert, Hermann, Handbuch der praktischen Medicin (Tübingen 1863)

Lemonick, David D., "Teens Before Their Time," Time (October 30, 2000) 66-74

Leppert, Richard, "Social Order and the Domestic Consumption of Music," in: Ann Bermingham and John Brewer (eds), The Consumption of Culture (London 1995) 514-534

Leppert, Richard, Music and Image (Cambridge 1998)

Levillian, L., Hygiène des Gens Nerveux (Paris 1901)

Lichtenthal, Peter, Der musikalische Arzt, oder: Abhandlung von dem Einflusse der Musik auf den Körper, und von ihrer Anwendung in gewissen Krankheiten. Nebst einigen Winken, zur Anhörung einer guten Musik (Vienna 1807)

Martensen, Robert, "The Transformation of Eve: Women's Bodies, Medicine and Culture in Early Modern England," in: Roy Porter/Mikulas Teich (eds), Sexual Knowledge, Sexual Science: The History of Attitudes towards Sexuality (Cambridge 1994) 107-133

Maudsley, Henry, "Sex in Mind and Education," Fortnighly Review 21 (1874) 466-483

Nicolai, Ernst Anton, Die Verbindung der Musik mit der Arzneygelahrheit (Halle 1745)

Norbury, Frank Parsons, "Nervousness in Young Women:Its Mechanism and Some of its Causes," The Medical Fortnightly 9-10 (1896) 110-113

Nye, Robert/Katherine Park, "Destiny is Anatomy," The New Republic (18.2.1991) 52-57

Oppenheim, Hermann, Nervenkrankheit und Lektüre, Nervenleiden und Erziehung (Berlin 1907)

Pick, Daniel, Faces of Degeneration (Cambridge 1989)

Porter, Roy, "Reading is Bad for Your Health," History Today 48 (1988) 11-16

Porter, Roy "Nervousness, Eighteenth and Nineteenth Century Style: From Luxury to Labour," in: Marijke Gijswijt-Hofstra/Roy Porter (eds), Cultures of Neurasthenia (Amsterdam 2001) $31-50$

Pudor, Heinrich, Wiedergeburt in der Musik! (Dresden 1892)

Rabinbach, Anson, The Human Motor: Energy, Fatigue, and the Origins of Modernity (New York 1990)

Raciborski, Adam, Traité de la Menstruation (Paris 1868)

Reich, Eduard, System der Hygiene (Leipzig 1871)

Reich, Eduard, Die Ursachen der Krankheiten, der Physischen und Moralischen (Leipzig 1872)

Roelcke, Volker, Krankheit und Kulturkritik: Psychiatrische Gesellschaftsdeutungen im bürgerlichen Zeitalter (1790-1914) (Frankfurt 1999) 112-121

Rosenberg, Charles, "The Place of George M. Beard in nineteenth-century Psychiatry," Bulletin of the History of Medicine 36 (1962) 245-259

Rouy, Hersilie, Memoires d'une Aliénée (Paris 1883)

Sargant, William, The Mind Possessed: A Physiology of Possession, Mysticism and Faith Healing (Philadelphia 1974) 
Shail, Andrew/Gillian Howie (eds), Menstruation: A Cultural History (Basingstoke 2005)

Showalter, Elaine, "Victorian Women and Menstruation," Victorian Studies 14 (1970) 83-89

Sicherman, Barbara, "The Uses of a Diagnosis: Doctors, Patients and Neurasthenia," Journal of the History of Medicine 32 (1977) 33-54

Skene, Alexander, Education and Culture: As Related to the Health (Detroit 1889)

Smith-Rosenberg, Carroll/Charles Rosenberg, "The Female Animal: Medical and Biological Views of Woman and her Role in Nineteenth-Century America," The Journal of American History 60 (1973) 332-356

Stolberg, Michael, "The Anatomy of Sexual Difference in the Sixteenth and Seventeenth Centuries," Isis 94 (2003) 274-299

Tait, Lawson Diseases of Women (London 1877)

Tait, Lawson, The Pathology and Treatment of Diseases of the Ovaries (New York 1880)

Tait, Lawson, Diseases of the Ovaries (London 1883)

Thorburn, John, Female Education from a Physiological Point of View (London 1884)

Tilt, Edward John, On Diseases of Menstruation and Ovarian Inflammation (New York 1851)

Ufer, Christian, Nervosität und Mädchenerziehung in Haus und Schule (Wiesbaden 1890)

Vertinsky, Patricia, The Eternally Wounded Woman (Manchester 1990)

Wagner, Ludwig, Unterricht und Ermüdung (Berlin 1898)

Walker, Anne E., The Menstrual Cycle (London 1997)

Wehner, R., Enzyklopädisches Handbuch der Schulhygiene (Vienna and Leipzig 1904)

Westmacott, A.B., The Power of Sound, or The Effect of Music with a Moral (London 1879)

Weyl, Theodor, Handbuch der Hygiene, 11 Vols. (Leipzig 1914)

W.F., "Das klägliche Ende der allgemeinen Musiksucht" Musikalisches Wochenblatt 30 (1899) 636-637

Wilson, Susannah, Voices of the Asylum (Oxford 2010)

Witte, "Können Frauen Klavierstimmerinnen werden?" Musikpädagogische Blätter 16 (October 15, 1893) 261-263

Wolf, Max, Die physische und sittliche Entartung des modernen Weibes (Dresden 1896)

Work, Hubert, "The Education of Girls," The Medical Fortnightly 9-10 (1896) 220-223 